Journal Universitas Muhammadiyah Gresik Engineering, Social Science, and Health International Conference (UMGESHIC)

UMGCINMATIC : $1^{\text {st }}$ Rethinking Education during Covid-19 Era: Challange and Innovation

\title{
Listening Barriers in English Proficiency Test in English Education Department of Universitas Muhammadiyah Gresik
}

\author{
Author \\ Paulina $^{1}$, Qothrunnada Almubarokah ${ }^{2}$, Farah Natchiar Binti Mohd Khaja ${ }^{3}$, Abdul \\ Ghani Bin Abu ${ }^{4}$ \\ ${ }^{1}$ Mahasiswa, Universitas Muhammadiyah Gresik \\ ${ }^{2,3,4}$ Pendidikan Sultan Idris, Universitas Muhammadiyah Gresik \\ Corresponding author: paulina@umg.ac.id
}

\begin{abstract}
English Proficiency Test (EPT) has been utilized widely to measure the skills of English learners. On the other hand, each test has its challenges and uniqueness. This current research aims to investigate the specific problem encountered by English language learners during English Proficiency Test (EPT) in Universitas Muhammadiyah Gresik. The problem is specific to listening where a lot of learners frequently have difficulties. Participants of this study are 30 Learners from the English education department of Universitas Muhammadiyah Gresik from the 3rd to the 5th semester. The result reveals that among the common challenges in listening skills in EPT, the most frustrating barrier is the occurrence of unfamiliar words, including jargon and idioms. There are $60 \%$ who agree that it is the most challenging part, while only 3.3\% do not. It may happen as Idioms will be extremely hard for several students since idioms are similar to describe a genuine position regardless theportray of other situations with different meanings. The following research is encouraged to investigate other aspects of English skills in the EPT and more participants to discover the appropriate method to tackle the barriers.
\end{abstract}




\section{INTRODUCTION}

English Proficiency Test (EPT) has been used for a long time and plays a critical role in measuring the language skills of L2 learners in educational institutions. One commonly used EPT is TOEFL (Test of English as a Foreign Language). There are more than 9.000 education institutions from universities and colleges that accept TOEFL scores worldwide. The official website of Educational Testing Service (ETS) in 2013 stated that Agencies and institutions rely on TOEFL scores as well; immigration departments use them to issue residential and work visas, medical and licensing agencies use them for professional certification purposes, individuals use them to measure their progress in learning English.

Among the other aspects of English skills, attention to research in listening skills is scant, despite the importance of listening skills in both learning and communication. It is still the least searched skill of all language skills [1]. One factor happens to be the reason is in cognitive, the listening skill places the high difficulty level. It means that this skill requires the complete attention [2]. In listening, there is no way to go back to the previous passage to review or ensure comprehension [2], [3]. Furthermore, the speech in listening for the L2 learners tends to be fast. The excessive listening speed can lessen the learners' comprehension with lower intermediate [3]. The increase in the speech rate influences comprehension. It reduces comprehension and makes it a critical barrier [3].

During the English Proficiency Test (EPT), language learners with lower proficiency will suffer the listening part since it requires high concentration and mostly has difficulties in this part compared to other skills. The barriers in listening were investigated by [4] who are getting the wrong sense of the word even when learners are familiar with it. Other than that, barriers in phonemic, lexical, and syntactic are found during the listening process.

Preliminary studies about barriers to listening in EPT have been conducted on L2 learners. However, there are still least studies about the specific barriers in the listening section. This study investigates the specific barrier in listening that becomes a problematic barrier that happens in EPT at Universitas Muhammadiyah Gresik. By knowing the reason behind the problems will encourage the educators to assist the learners to or overcome the barrier in listening [5]

\section{METHODS}

\subsection{Research designs}

The study aims to investigate the most problematic barrier in the listening section in English Proficiency Test (EPT), mainly in TOEFL in English education department learners of Universitas Muhammadiyah Gresik. The study investigated the percentage of each aspect of the listening section in EPT that is the most challenging and, the 
participants of the study were not allowed to conduct a face-to-face interview due to the pandemic situation. Therefore, this study utilizes the quantitative survey method.

\subsection{Study participants}

30 learners of the English education department of Universitas Muhammadiyah Gresik were joining the study. The age was ranged from 19-21. The learners consist of two semesters which are the 3 rd and 5 th semesters. The reason the researchers decided the certain semesters was because they have had an Extensive Listening course which discussed the English Proficiency Tests, mainly TOEFL. Therefore, they acquire the background knowledge of the test. It gives more accurate data about the listening section in EPT than the first semester learners who have not obtained the course and the seventh semesters who have been doing their thesis.

\subsection{Instruments}

Aquantitative survey questionnaire was addressed to the learners to measure the barriers have encountered during the listening section in EPT. The questionnaire was distributed by a single link of Google Form and sent to each semester learners through the chief of the class. The form provides a simple interface to construct various question types (multiplechoice, short answer, long answers, drop-down menus, etc. [6].

The questionnaire was modified from the research conducted by [7]. It consisted of several categories according to the kind of barriers in listening and used 5 point of Likert scale where 1 represents to "Strongly disagree" and 5 represents to "Strongly agree". The questions are closed and divided by several aspects in listening section of EPT.

The questions were divided into some categories:

1) Problems with unfamiliar topics/materials (7 items)

2) Problems with audio length (5 items)

3) Problems with low comprehension/listener (5 items)

4) Problems with unfamiliar vocabularies (6 items)

5) Problems with speed of the speech (2 items)

6) Problems with speaker (3 items)

\subsection{Data collection}

The data were collected through an online questionnaire from google form. The link was delivered to the chief of each semester, and they will share it with other learners. The learners were given 20-30 minutes to fill the questionnaire. The language of the questionnaire is in English, and the instruction was given in Bahasa Indonesia to avoid bias and misunderstanding. It was stated that a questionnaire could be used to collect information about the number of participants (populations) or small groups (samples) [8] 


\subsection{Data analysis}

The quantitative data were acquired from the answers in the google form. It is based on the aspect of problems in the listening section in EPT. The result was then elaborated by the descriptive research method. It gives detailed information regarding a problem based on phenomena that happened. It examines the character of the problem and describes the issue

\begin{tabular}{|l|l|l|l|l|l|l|}
\hline No & \multicolumn{1}{|c|}{ STATEMENTS } & $\mathbf{1}$ & $\mathbf{2}$ & $\mathbf{3}$ & $\mathbf{4}$ & $\mathbf{5}$ \\
\hline 1 & I find the topic in section A is unfamiliar & $10.3 \%$ & $26.7 \%$ & $30 \%$ & $23.3 \%$ & $10 \%$ \\
\hline 2 & I find the topic in section B is unfamiliar & $3.3 \%$ & $33.3 \%$ & $26.7 \%$ & $23.3 \%$ & $13.3 \%$ \\
\hline 3 & I find the topic in section C is unfamiliar & $3.3 \%$ & $20 \%$ & $16.7 \%$ & $46.7 \%$ & $13.3 \%$ \\
\hline 4 & $\begin{array}{l}\text { I find the topic of the text unfamiliar with my experience and } \\
\text { background knowledge }\end{array}$ & $0 \%$ & $30 \%$ & $36.7 \%$ & $23.3 \%$ & $10 \%$ \\
\hline 5 & $\begin{array}{l}\text { I find the topic is not related to the materials taught in my } \\
\text { English course }\end{array}$ & $16.7 \%$ & $33.3 \%$ & $16.7 \%$ & $23.3 \%$ & $10 \%$ \\
\hline 6 & I find the topic is not related to my field of study & $6.7 \%$ & $26.7 \%$ & $26.7 \%$ & $23.3 \%$ & $16.7 \%$ \\
\hline 7 & I find some tricky answers on the options & $0 \%$ & $3.3 \%$ & $13.3 \%$ & $46.7 \%$ & $36.7 \%$ \\
\hline
\end{tabular}

specifically [9].

\section{FINDINGS}

This study aims to investigate the barrier in the listening section of EPT in the English education department from the 3rd to 5 th semester. There are some aspects that inference the barrier in the listening section. Here, the researchers will show the findings of the research based on different aspects of the listening section. All 30 learners answered all the questions thoroughly without any blanks. Therefore, researchers can obtain more objective and consistent results with an equal number of answers for each question. The result will be elaborated based on separated tables in the following:

\begin{tabular}{|l|l|l|l|l|l|l|}
\hline No & \multicolumn{1}{|c|}{ STATEMENTS } & $\mathbf{1}$ & $\mathbf{2}$ & $\mathbf{3}$ & $\mathbf{4}$ & $\mathbf{5}$ \\
\hline 1 & I find the topic in section A is unfamiliar & $10.3 \%$ & $26.7 \%$ & $30 \%$ & $23.3 \%$ & $10 \%$ \\
\hline 2 & I find the topic in section B is unfamiliar & $3.3 \%$ & $33.3 \%$ & $26.7 \%$ & $23.3 \%$ & $13.3 \%$ \\
\hline 3 & I find the topic in section C is unfamiliar & $3.3 \%$ & $20 \%$ & $16.7 \%$ & $46.7 \%$ & $13.3 \%$ \\
\hline 4 & $\begin{array}{l}\text { I find the topic of the text unfamiliar with my experience and } \\
\text { background knowledge }\end{array}$ & $0 \%$ & $30 \%$ & $36.7 \%$ & $23.3 \%$ & $10 \%$ \\
\hline 5 & $\begin{array}{l}\text { I find the topic is not related to the materials taught in my } \\
\text { English course }\end{array}$ & $16.7 \%$ & $33.3 \%$ & $16.7 \%$ & $23.3 \%$ & $10 \%$ \\
\hline 6 & I find the topic is not related to my field of study & $6.7 \%$ & $26.7 \%$ & $26.7 \%$ & $23.3 \%$ & $16.7 \%$ \\
\hline 7 & I find some tricky answers on the options & $0 \%$ & $3.3 \%$ & $13.3 \%$ & $46.7 \%$ & $36.7 \%$ \\
\hline
\end{tabular}

Table 1.

\section{Problems with Unfamiliar topics/Materials}

The first table draws the result in terms of the unfamiliarity of the topics or materials in the listening section. There are seven specific items related to the aspect. The first until third items showed the topic familiarity of each listening section in EPT. The result affirmed that $23.3 \%$ of learners are unfamiliar with sections A and B. However, $46.7 \%$ of learners are more unfamiliar with section $\mathrm{C}$. However, it can be concluded that learners have not explored section $\mathrm{C}$ yet. The following statement was dealing with the text's unfamiliarity. It is related to the learner's 
background knowledge and experience. It showed that all students are familiar with the topic of the listening section, as the result of $30 \%$ of them answering disagree. The next statement is about the relation between the topic of the listening and what they have learned in their course. $33.3 \%$ of learners stated that they learn the same material with the topic in the listening section. Moreover, the following statement investigated the relationship between the field of study and the topic in the listening section. Just like the previous item, students agreed that the topic is related to their field of study with a percentage of $26.7 \%$. The last item is about how learners feel about the answer options in the listening section. Surprisingly, $46.7 \%$ of them agree that the answer options are tricky, and only a small number of learners can overcome the trickiness $(3.3 \%)$.

\begin{tabular}{|c|c|c|c|c|c|c|}
\hline NO & STATEMENTS & 1 & 2 & 3 & 4 & 5 \\
\hline 1 & $\begin{array}{l}\text { I find Long spoken text interfered with my listening } \\
\text { comprehension. }\end{array}$ & $6.7 \%$ & $10 \%$ & $23.3 \%$ & $46.7 \%$ & $13.3 \%$ \\
\hline 2 & I find different audio length in each part & $0 \%$ & $10 \%$ & $23.3 \%$ & $43.3 \%$ & $23.3 \%$ \\
\hline 3 & I find the audio length in Part $\mathrm{A}$ is too long & $3.3 \%$ & $30 \%$ & $36.7 \%$ & $23.3 \%$ & $6.7 \%$ \\
\hline 4 & I find the audio length in Part B is too long & $0 \%$ & $16.7 \%$ & $46.7 \%$ & $26.7 \%$ & $10 \%$ \\
\hline 5 & I find the audio length in Part $\mathrm{C}$ is too long & $0 \%$ & $3.3 \%$ & $43.3 \%$ & $40 \%$ & $13.3 \%$ \\
\hline
\end{tabular}

Table 2.

\section{Problems with Audio Length}

The second table dealt with the issue related to the audio length. Item one examined the intervention of the conversation length with the learner's listening comprehension. It showed a significant result of the $46.7 \%$ of learners agreeing that the spoken text interfered with their listening comprehension. The following item investigated the audio length of each part of the listening section. It is found that learners are aware of the difference between each listening section with a number of $46.7 \%$. The last three parts were talking about the specific audio length for each section. In part A, 30\% of learners stated that the duration of the section is not too long. However, it is quite the opposite with section B where $26.7 \%$ of learners agree that the time is too long, and $46.3 \%$ tend to be neutral. Moreover, section $\mathrm{C}$ is also the same as the previous section. $40 \%$ of learners agree that part $\mathrm{C}$ is too long, and only $3.3 \%$ do not think so.

\begin{tabular}{|l|l|l|l|l|l|l|}
\hline NO & \multicolumn{1}{|c|}{ STATEMENTS } & $\mathbf{1}$ & $\mathbf{2}$ & $\mathbf{3}$ & $\mathbf{4}$ & $\mathbf{5}$ \\
\hline 1 & I find difficulty to understand listening section & $16.7 \%$ & $20 \%$ & $26.7 \%$ & $20 \%$ & $16.7 \%$ \\
\hline 2 & $\begin{array}{l}\text { I feel difficult to get a general understanding of the spoken } \\
\text { text from the first listening }\end{array}$ & $6.7 \%$ & $20 \%$ & $36.7 \%$ & $23.3 \%$ & $13.3 \%$ \\
\hline 3 & $\begin{array}{l}\text { I feel difficult to quickly remember words or phrases I have } \\
\text { just heard }\end{array}$ & $0 \%$ & $6.7 \%$ & $40 \%$ & $36.7 \%$ & $16.7 \%$ \\
\hline 4 & $\begin{array}{l}\text { I feel difficult to answer questions which require other than a } \\
\text { short answer (e.g. why or how questions). }\end{array}$ & $3.3 \%$ & $20 \%$ & $40 \%$ & $23.3 \%$ & $13.3 \%$ \\
\hline 5 & $\begin{array}{l}\text { I feel difficult to understand the meaning of words which are } \\
\text { not pronounced clearly }\end{array}$ & $6.7 \%$ & $6.7 \%$ & $20 \%$ & $30 \%$ & $36.7 \%$ \\
\hline
\end{tabular}

Table 3.

Problems with Low Comprehension/Listener 
The table above shows the barriers related to the comprehension of the learners. The first statement stated the struggle of understanding the listening section. There is a number $(20 \%$ each) between learners who struggle to comprehend and those who can deal with it. The following statement is about the difficulty of getting the general understanding of the spoken text from the first listening. The result tends to be neutral by $36.7 \%$ of learners that think so. However, the same result appears in the next statement. Learners experienced the struggle to remember the words and phrases they heard. The next statement is related to the "why" or "how" questions. 23.3\% of learners feel hard to answer those types of questions. Lastly, the statement was dealing with the difficulty to comprehend the words meaning when they are not pronounced clearly. Most learners agree that they have a problem understanding the word's meaning when it is not pronounced clearly (30\% and $36.7 \%)$.

\begin{tabular}{|c|c|c|c|c|c|c|}
\hline NO & STATEMENTS & 1 & 2 & 3 & 4 & 5 \\
\hline 1 & I find many unfamiliar words including jargon and idioms & $3.3 \%$ & $3.3 \%$ & $20 \%$ & $60 \%$ & $13.3 \%$ \\
\hline 2 & $\begin{array}{l}\text { I find many complex grammatical structures in listening } \\
\text { comprehension. }\end{array}$ & $0 \%$ & $16.7 \%$ & $36.7 \%$ & $26.7 \%$ & $20 \%$ \\
\hline 3 & $\begin{array}{l}\text { I feel difficult to understand every single word of incoming } \\
\text { speech }\end{array}$ & $6.7 \%$ & $26.7 \%$ & $30 \%$ & $16.7 \%$ & $20 \%$ \\
\hline 4 & $\begin{array}{l}\text { I find the pronunciation familiar for students but cannot } \\
\text { recognize the words }\end{array}$ & $0 \%$ & $10 \%$ & $50 \%$ & $26.7 \%$ & $13.3 \%$ \\
\hline 5 & $\begin{array}{l}\text { When encountering an unknown word, I stop listening and } \\
\text { think about the meaning of the word }\end{array}$ & $0 \%$ & $20 \%$ & $16.7 \%$ & $40 \%$ & $23.3 \%$ \\
\hline 6 & $\begin{array}{l}\text { I feel difficult to infer the meaning of an unknown word while } \\
\text { listening }\end{array}$ & $6.7 \%$ & $23.3 \%$ & $16.7 \%$ & $36.7 \%$ & $16.7 \%$ \\
\hline
\end{tabular}

\section{Table 4.}

\section{Problems with Unfamiliar Vocabularies}

The table above examined the barriers related to the vocabulary unfamiliarity. As shown in table 4, learners are not familiar with specific type of vocabularies such as jargon and idioms. More than half of the learners have a problem identifying jargon and idioms in the listening section. Moreover, the second statement was about the grammar complexity structure in listening. $26.7 \%$ of learners found many sophisticated grammatical structures during the listening section. However, the same result happened in the following statement. It is about the understanding of the single word of incoming speech. Learners seem not to have any difficulties understanding the single words of incoming speech. Moreover, half of the students tend to be neutral to be familiar with the pronunciation and word recognition. However, $26.7 \%$ of them do have difficulty recognizing the words. Furthermore, many students (40\%) choose to stop and think about the word's meaning during the listening section. The last statement is about the struggle to infer the meaning of the unknown words. More than $30 \%$ of learners have an obstacle to concluding the meaning of the new word that they have listened to. 
UMGCINMATIC: $1^{\text {st }}$ Rethinking Education during Covid-19 Era: Challange and Innovation Volume 1 No 2

\begin{tabular}{|l|l|l|l|l|l|l|}
\hline NO & \multicolumn{1}{|c|}{ STATEMENTS } & $\mathbf{1}$ & $\mathbf{2}$ & $\mathbf{3}$ & $\mathbf{4}$ & $\mathbf{5}$ \\
\hline 1 & I find the speakers are too fast & $0 \%$ & $10 \%$ & $16.7 \%$ & $40 \%$ & $33.3 \%$ \\
\hline 2 & I find the speaker does not pause long enough & $0 \%$ & $6.7 \%$ & $23.3 \%$ & $53.3 \%$ & $16.7 \%$ \\
\hline
\end{tabular}

Table 5.

Problems with speed of the speech

The following table dealt with the speed of the speech. The first item was related to the speaker's speed on the audio. Above 30\% agreed that the speakers speak too fast, and they struggled with it. Furthermore, more than half of the learners (53.3\%) agreed that the speakers do not pause the audio and tend to speak on and on.

\begin{tabular}{|c|c|c|c|c|c|c|}
\hline NO & STATEMENTS & 1 & 2 & 3 & 4 & 5 \\
\hline 1 & $\begin{array}{l}\text { I found the intonation of the speaker trick me to answer the } \\
\text { question }\end{array}$ & $0 \%$ & $13.3 \%$ & $20 \%$ & $46.7 \%$ & $20 \%$ \\
\hline 2 & $\begin{array}{l}\text { I feel difficult to understand the natural speech from the native } \\
\text { speaker }\end{array}$ & $0 \%$ & $20 \%$ & $30 \%$ & $30 \%$ & $20 \%$ \\
\hline 3 & I find some words are not pronounced clearly & $0 \%$ & $6.7 \%$ & $26.7 \%$ & $33.3 \%$ & $33.3 \%$ \\
\hline
\end{tabular}

\section{Table 6.}

\section{Problem with speaker}

The last table dealt with the issue related to the speaker themselves. There are three items in the table and the majority of the students are agreed on each item. The first item is dealing with the intonation of the speakers. $46.7 \%$ of learners encountered that the speaker's intonation is tricky, which makes them hard to answer the questions. The second item in the table is related to speech understanding. $30 \%$ of learners agreed that they are struggling with understanding the speech from native speakers. However, the same percentage of the learners tend to be neutral, and none of them disagrees. Finally, the ultimate item is related to word pronunciation. Most of the learners (33.3\%) agreed that they faced difficulty understanding the pronunciation because it was not clear for them.

\section{DISCUSSION}

This research investigates the barriers related to the listening section in EPT, particularly in TOEFL. Gender is neglected and will not influence the result of the questionnaire. In EPT, listening is divided into three sections based on their complexity. Section A consist of short dialogs for each question and involve sixteen grammatical aspects including synonyms, similar sounds, identifying location, speaker and activity, passives, multiple nouns, negative expressions, double negative expressions, "almost negative" expressions, negative with comparatives, agreement expressions, uncertainty and suggestion expressions, empathic surprise expressions, wishes, false conditions, two- and three-part verbs, idioms [10]. Section 
$\mathrm{B}$ and $\mathrm{C}$ have a long conversation and mostly will cover 2-3 questions for each talk. The main difference between them is section B still contains the conversation between two people, while section C only contains a single talk from one person (monologue) [10].

The result of the questionnaire presented in separated tables according to each problem category, including problems with unfamiliar topics/materials, problems with audio length, problems with low comprehension/listener, problems with unfamiliar vocabularies, problems with the speed of the speech, the problem with the speaker.

Moreover, the most challenging barrier in the listening section in EPT among those aspects is the unfamiliarity of the jargon and idioms. It is following the preliminary research by [11] who analyzed the failure in EFL listening comprehension. It is clearly stated that one of the listening barriers is the unfamiliar jargon. This phenomenon happens as jargons are varied and have particular use in an academic and specific time and places. Therefore, it makes jargon become a barrier that needs much more attention than other aspects [12]. Furthermore, the unfamiliarity of the jargon and idioms can arise when learners have limited vocabulary. It is stated by [13] that the listeners must acquire the appropriate amount of vocabulary to understand a passage in a different language. However, during the listening section, learners will face unfamiliar idioms and jargon. It makes them cannot obtain the information and message given. Other aspects that can influence listening comprehension are the lack of grammar, speech length, unfamiliarity with the topics [14].

\section{CONCLUSION}

To sum up, each listening section has its difficulty. According to the result percentage, it can be concluded that each student experiences different struggles during the listening section. Even for the simple thing as determining the topic of the listening section, it is still quite problematic. Moreover, the barrier that seems to be the most problematic is related to the unfamiliarity with jargon and idioms. It is caused by various components and needs to be overcome urgently. Therefore, it is highly suggested for the following research to investigate the best way to conduct a learning activity to improve learners' listening skills, especially in the aspects that have been mentioned above.

\section{REFERENCES}

W. A. Renandya, F. A. Hamied, and J. Nurkamto, "English language proficiency in Indonesia: Issues and prospects, ” Journal of Asia TEFL, vol. 15, no. 3, pp. 618-629, Sep. 2018, doi: 10.18823/asiatefl.2018.15.3.4.618.

T. Ridgway, "Listening strategies-I beg your pardon?," 2000. [Online]. Available: http://eltj.oxfordjournals.org/ 
W. A. Renandya and T. S. C. Farrell, “'Teacher, the tape is too fast!' Extensive listening in ELT,” ELT Journal, vol. 65, no. 1, pp. 52-59, Jan. 2011, doi: 10.1093/elt/ccq015.

J. Field, "Promoting perception: lexical segmentation in L2 listening The importance of," 2003.

A. Hargreaves, "Four ages of professionalism and professional learning," Teachers and Teaching: Theory and Practice, 2000.

R. Talbert, Flipped learning : a guide for higher education faculty. Sterling, Virginia: Stylus Publishing, LLC., 2017.

A. Hamouda, "International Journal of Academic Research in Progressive Education and Development," An Investigation of Listening Comprehension Problems Encountered by Saudi Students in the EL Listening Classroom, vol. 2, no. 2, 2013.

D. E. McNabb, Research Methods for Political Science, 2nd ed. New York, NY: M.E. Sharpe, 2010. J. Collis and R. Hussey, "Business Research: A Practical Guide for Undergraduate and Postgraduate Students, ” New York, NY, 2009.

Rainy, Ikhsanudin, and Sumarni, "Analyzing students' TOEFL listening comprehension test performance," Journal Untan, vol. 3, no. 10, 2014.

Ahmed Benyo and Tribhuwan Kumar, "An Analysis of Indian EFL Learners' Listening Comprehension Errors," The Asian ESP Journal, vol. 16, no. 5.2, pp. 98-117, 2020.

G. G. Sumalinog, "Factors Affecting the Listening Comprehension Skills of the Foreign students ," International Review of Social Sciences, vol. 6, no. 11, 2008.

I. S. P. Nation, Learning Vocabulary in Another Language. Cambridge University Press, 2001.

S. Robiah, "problems in listening comprehension of advanced listening comprehension students thesis Submitted in Partial Fulfillment of the Requirement for Gaining The Degree of Bachelor of Education in English Language Education," 2019. 